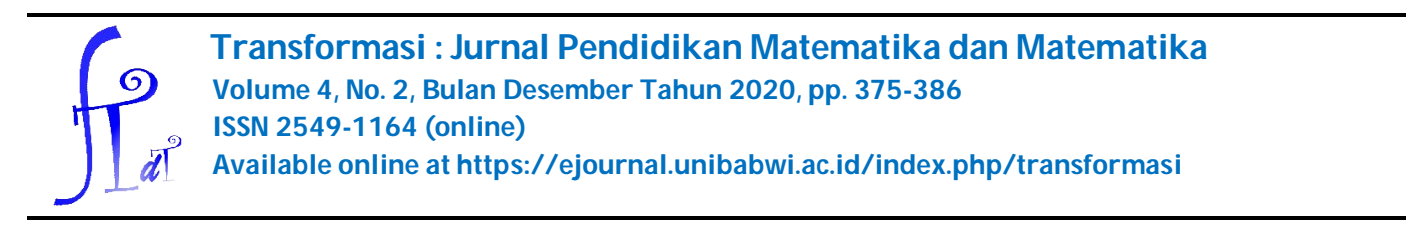

\title{
ANALISIS SURVIVAL WAKTU SEMBUH PASIEN COVID-19 DI KABUPATEN BANYUWANGI
}

\author{
Sulantari ${ }^{1}$, Wigid Hariadi ${ }^{2}$ \\ 1,2 FP MIPA, IKIP PGRI JEMBER \\ email korespondensi : sulantari89@gmail.com
}

\begin{abstract}
Diterima : (18-10-2020), Revisi: (12-12-2020), Diterbitkan : (24-12-2020)
ABSTRAK

Analisis survival adalah salah satu analisis data statistika yang bertujuan untuk melakukan analisis fungsi survival (waktu sembuh). Pertanggal 30 Juli 2020 sebanyak 108.376 orang positif covid-19, dengan 65.907 pasien dinyatakan sembuh dan 5.131 pasien meninggal dunia di Indonesia. Sementara itu di kabupaten Banyuwangi tercatat sebanyak 56 orang positif Covid-19 dengan 44 pasien sembuh dan 2 pasien meninggal. Tingginya angka kematian tersebut menunjukkan bahwa virus covid-19 ini sangat berbahaya bagi manusia. Namun demikian angka kesembuhan virus ini juga cukup tinggi. Untuk itu dilakukan analisis survival waktu sembuh pasien covid-19 di Banyuwangi dengan uji Kaplan-Meier sebagai penghitung estimasi fungsi survival (waktu sembuh) pasien Covid-19, uji Log-Rank untuk menguji adanya perbedaan fungsi survival ( $\mathrm{S}(\mathrm{t})$ ) waktu sembuh pasien Covid-19 pada dua kelompok. Data yang digunakan adalah data pasien Covid-19 di Kabupaten Banyuwangi sejak Mei sampai 27 Juli 2020. Kesimpulan yang diperoleh adalah median fungsi survival waktu sembuh pasien Covid-19 di Kabupaten Banyuwangi adalah 16 hari perawatan, dengan fungsi survival waktu sembuh pasien laki-laki memiliki median 15,5 hari perawatan dan fungsi survival waktu sembuh pasien perempuan memiliki median 13 hari perawatan. Namun, berdasarkan uji Log-Rank dengan $\alpha=0,05$, disimpulkan tidak terdapat perbedaan yang signifikan pada lama waktu sembuh Covid-19 antara pasien perempuan dan pasien laki-laki.

Kata kunci : Covid-19, Analisis Survival, Kaplan-Meier, Log-Rank
\end{abstract}




\begin{abstract}
Survival analysis is a statistical data analysis that aims to analyze the survival function (recovery time). As of July 30, 2020, there were 108,376 positive people for Covid-19, with 65,907 patients declared cured and 5,131 patients dying in Indonesia. Meanwhile in Banyuwangi district there were 56 positive people for Covid-19 with 44 patients recovering and 2 patients dying. The high mortality rate shows that the Covid-19 is very dangerous for humans. For this reason, a survival analysis for Covid-19 patients' recovery time in Banyuwangi was carried out with the Kaplan-Meier test as a calculation of the estimated survival function (recovery time) of Covid-19 patients, the Log-Rank to test for differences in the survival function $(\mathrm{S}(\mathrm{t})$ ) of recovery time. Covid-19 patients in two groups. The data used is data on Covid-19 patients in Banyuwangi Regency from May to July 27, 2020. The conclusion obtained is that the median survival time function for Covid-19 patients in Banyuwangi Regency is 16 days of treatment, with the survival function for male patients having a median of 15.5 days of treatment and the survival function for female patients having a median of 13 days of treatment. However, based on the Log-Rank test with $\alpha=$ 0.05 , it was concluded that there was no significant difference in the length of time to recover from Covid-19 between female patients and male patients.
\end{abstract}

Key words: Covid-19, Survival Analysis, Kaplan-Meier, Log-Rank

\title{
Pendahuluan
}

Virus Corona atau severe acute respiratory syndrome coronavirus 2 (SARS-CoV-2) adalah virus yang menyerang sistem pernapasan. Virus Corona menyebabkan gangguan ringan pada sistem pernapasan serta infeksi paru-paru yang berat, sehingga akan mengalami kesulitan bernapas dan ditandai dengan pneumonia yang merupakan kondisi paru-paru yang mengalami radang. Kondisi ini dapat menyebabkan paru-paru kekurangan oksigen. Akibatnya, suplai oksigen ke organ lain pun ikut berkurang sehingga mengakibatkan kegagalan organ. Kegagalan organ tersebut yang kemudian menyebabkan kematian hingga kematian (Pane, 2020).

Corona virus biasanya menyebabkan penyakit infeksi saluran pernapasan, mulai flu biasa hingga penyakit yang serius seperti Middle East Respiratory Syndrome (MERS) dan Sindrom Pernafasan Akut Berat/ Severe Acute Respiratory Syndrome (SARS). Corona virus jenis baru yang ditemukan pada manusia sejak kejadian luar biasa muncul di Wuhan Cina, pada Desember 2019, kemudian diberi nama Severe Acute Respiratory Syndrome) Corona virus 2 (SARS-COV2), dan menyebabkan penyakit Corona virus Disease-2019 (COVID-19). Indonesia mengumumkan adanya kasus covid-19 sejak bulan Maret 2020. Adapun kelompok yang rentan terinfeksi virus corona adalah orang lanjut usia (lansia), orang dengan riwayat penyakit tertentu, 
tenaga medis di rumah sakit, serta anak-anak (Ikhsania, 2020).

Jumlah pasien terinfeksi virus Corona semakin tinggi dengan jumlah kematian yang tidak rendah. Menurut Kementerian Kesehatan Republik Indonesia (2020), pertanggal 22 Agustus 2020 jumlah pasien positif Corona sebesar 169.195 pasien dengan jumlah pasien yang sembuh sebesar 122.802 pasien dan jumlah pasien yang meninggal sebanyak 7.261 pasien. Sementara itu, kabupaten Banyuwangi menjadi salah satu daerah di Indonesia yang juga terdampak Covid-19. Pertanggal 21 Agustus 2020, tercatat sebanyak 187 orang yang positif Covid-19 dengan 77 orang dinyatakan sembuh, 5 orang dinyatakan meninggal, dan selebihnya masih dalam perawatan (banyuwangikab.go.id, 2020). Hal ini menegaskan bahwa Corona virus (Covid-19) merupakan ancaman kesehatan yang serius bagi masyarakat di Banyuwangi.

Metode Kaplan-Meier adalah modifikasi dari fungsi yang dapat digunakan untuk menangani masalah data tak lengkap (Lawless, 2003). Uji Kaplan-Meier merupakan salah satu uji statistika yang digunakan untuk menghitung estimasi fungsi survival $\mathrm{S}(\mathrm{t})$. Metode Kaplan-Meier memberikan gambaran dalam tampilam grafik tentang distribusi tahan hidup (Cook, 2008). Sedangkan uji Log-Rank merupakan uji untuk membandingkan dua kelompok yang berkaitan, dengan kondisi yang berbeda. Melalui uji Log-Rank dapat diketahui apakah kedua kelompok tersebut memiliki fungsi survival S(t) yang sama atau tidak secara statistik. Uji Kaplan-Meier banyak diaplikasikan dalam bidang kesehatan, diantaranya Uji Kaplan-Meier dapat menggambarkan karakteristik pasien berupa peluang survival pasien HIV/ AIDS memiliki stadium berat lebih rendah daripada pasien yang memiliki stadium ringan, sehingga faktor stadium memberikan pengaruh terhadap survival pasien HIV/ AIDS (Kusumawardani, 2016). Dengan analisis Kaplan-Meier dapat memberikan gambaran bahwa ketahanan hidup pasien usia 46-65 tahun lebih rendah dari pada pasien usia 26-45 tahun untuk pasien penyakit ginjal kronis dengan hemodialisis (Yulianto, dkk., 2017).

Melihat tingginya kasus positif Covid-19 di Banyuwangi, memberikan ide untuk melakukan penelitian tentang analisis survival lama waktu sembuh pasien Corona virus (Covid-19) di Kabupaten Banyuwangi. Tujuan penelitian ini adalah : (1) untuk mengetahui estimasi fungsi survival/ lama waktu sembuh $(\mathrm{S}(\mathrm{t}))$ pasien Corona virus (Covid-19) di Kabupaten Banyuwangi; (2) untuk mengetahui apakah terdapat perbedaan lama waktu sembuh antara pasien laki-laki dan pasien perempuan; dan (3) 
untuk mengetahui apakah terdapat perbedaan lama waktu sembuh antara pasien yang berusia kurang dari 40 tahun dengan pasien berusia diatas 40 tahun.

\section{Metode Penelitian}

Penelitian dilakukan di wilayah Kabupaten Banyuwangi, Jawa Timur. Sasaran dalam penelitian ini adalah pasien covid-19 yang telah dinyatakan sembuh. Data yang digunakan dalam penelitian ini adalah data sekunder yang berisi data pasien covid-19 di wilayah kabupaten Banyuwangi yang diperoleh melalui publikasi Pemkab Banyuwangi (dalam banyuwangikab.go.id), yang mencantumkan data informasi pasien Covid-19 meliputi jumlah pasien yang positif, sedang dirawat, sudah sembuh, dan pasien meninggal. Periode pengambilan data dilakukan sejak 23 Mei sampai 27 Juli 2020.

Populasi dalam penelitian ini adalah seluruh pasien positif covid-19 di kabupaten Banyuwangi sampai tanggal 27 Juli 2020, yang tercatat sebanyak 56 pasien. Sedangkan sampelnya diambil sebanyak 30 pasien covid-19 yang telah dinyatakan sembuh. Perhitungan sampel dilakukan dengan menggunakan rumus Slovin, dengan tingkat signifikansi ( $\alpha$ ) sebesar 0,125. Pemilihan tingkat signifikansi dilakukan karena untuk sampel kecil pada rumus Slovin, diberikan toleransi tingkat signifikansi $(\alpha)$ sampai dengan 0,2. Adapun rumus Slovin untuk menentukan ukuran sampel minimal sebagai berikut.

$$
n=\frac{N}{1+N\left(\alpha^{2}\right)}
$$

Dengan $: \mathrm{n}$ : adalah sampel minimal

$\mathrm{N}$ : ukuran populasi

$\alpha \quad$ : tingkat signifikansi

Tipe data yang digunakan adalah data tersensor kanan tipe II. Data tersensor kanan bermakna bahwa penelitian dilakukan dengan melakukan pengamatan kepada pasien sejak pasien mulai dinyatakan positif covid-19 dan dirawat sampai pasien tersebut sembuh. Sedangkan data tersensor tipe II yaitu penelitian/pengamatan akan berhenti setelah diperoleh sejumlah tertentu pasien sembuh (r). Pengamatan dihentikan setelah diperoleh 30 pasien yang sembuh.

Analisis data dilakukan dengan uji Kaplan-Meier dan uji Log Rank. Uji Kaplan-Meier bertujuan untuk menentukan estimasi fungsi survival ( $\mathrm{S}(\mathrm{t})$ ) dan menampilkan grafik fungsi survival $(\mathrm{S}(\mathrm{t})$ ). Fungsi survival $\mathrm{S}(\mathrm{t})$ digunakan untuk me- 
nyatakan probabilitas suatu objek sampai tidak terjadinya suatu event. S(t) merupakan estimasi fungsi survival atau probabilitas waktu survival lebih besar dari t dinyatakan sebagai berikut.

$$
S(t)=P(T>t)=1-F(t)=1-P(T \leq t)
$$

Fungsi survival untuk suatu interval waktu adalah proporsi jumlah subjek survive pada awal interval dikurangi jumlah kegagalan dalam interval tersebut.

$$
\hat{S}\left(t_{i}\right)=\frac{N_{i-1}-d_{i}}{N_{i-1}}
$$

Uji Log-Rank merupakan uji untuk membandingkan dua kelompok yang berkaitan, dengan kondisi yang berbeda. Melalui uji Log-Rank dapat diketahui apakah kedua kelompok tersebut memiliki fungsi survival S(t) yang sama secara statistik atau tidak. Uji Log-Rank menggunakan hipotesis :

Ho : $\mathrm{S}_{1}(\mathrm{t})=\mathrm{S}_{2}(\mathrm{t})$ (terdapat perbedaan yang signifikan antara 2 fungsi survival) $\mathrm{H}_{1}: \mathrm{S}_{1}(\mathrm{t}) \neq \mathrm{S}_{2}$ (t) (tidak terdapat perbedaan yang signifikan antara 2 fungsi survival) Dengan daerah kritisnya adalah tolak $\mathrm{H}_{0}$ jika $\mathrm{P}$-value < tingkat signifikansi $(\alpha)$.

\section{Hasil dan Pembahasan}

\section{Analisis Metode Kaplan-Meier}

Fungsi survival S(t) dalam penelitian ini adalah lama waktu sembuh pasien Covid-19 di wilayah Kabupaten Banyuwangi. Selanjutnya akan dilihat bagaimana fungsi survival $(\mathrm{S}(\mathrm{t})$ ) pasien terhadap suatu perlakuan (perawatan). Berikut ditampilkan plot data antar kejadian waktu sembuh pasien covid-19 sebanyak 30 orang yang terpilih menjadi sampel. Kriteria sampel adalah pasien Covid-19 di Kabupaten Banyuwangi yang diketahui informasi tanggal dinyatakan positif Covid-19 dan tanggal dinyatakan sembuh Covid-19, sehingga dapat dihitung lama waktu sembuh setelah dirawat oleh tenaga medis. Data serta plot antar kejadian dari sampel terpilih adalah sebagai berikut: 
Tabel 1. Data Pasien Sembuh Covid-19 Setelah Dirawat

\begin{tabular}{|c|c|c|c|c|c|c|c|c|c|}
\hline PASIEN KE- & STATUS & \begin{tabular}{c|} 
LAMA \\
PERAWATAN (Hari) \\
\end{tabular} & Jenis KELAMIN & UMUR (Th) & PASIEN KE- & STATUS & \begin{tabular}{c|} 
LAMA \\
PERAWATAN (Hari) \\
\end{tabular} & Jenis KELAMIN & UMUR (Th) \\
\hline 1 & sembuh & 16 & $*$ & * & 23 & sembuh & 16 & laki-laki & 58 \\
\hline 7 & sembuh & 4 & laki-laki & 24 & 24 & sembuh & 20 & perempuan & 41 \\
\hline 3 & sembuh & 53 & * & $*$ & 25 & sembuh & 15 & laki-laki & 45 \\
\hline 6 & sembuh & 19 & * & * & 26 & sembuh & 17 & laki-laki & $*$ \\
\hline 10 & sembuh & 16 & perempuan & * & 30 & sembuh & 17 & * & 28 \\
\hline 11 & sembuh & 18 & * & * & 32 & sembuh & 17 & pria & 24 \\
\hline 12 & sembuh & 9 & laki-laki & 33 & 33 & sembuh & 8 & pria & 60 \\
\hline 19 & sembuh & 13 & laki-laki & 23 & 34 & sembuh & 4 & * & * \\
\hline 8 & sembuh & 42 & laki-laki & 25 & 40 & sembuh & 5 & perempuan & 60 \\
\hline 14 & sembuh & 29 & laki-laki & 26 & 41 & sembuh & 5 & * & 24 \\
\hline 16 & sembuh & 29 & laki-laki & 25 & 42 & sembuh & 10 & perempuan & 49 \\
\hline 18 & sembuh & 21 & perempuan & 41 & 43 & sembuh & 10 & perempuan & 22 \\
\hline 20 & sembuh & 26 & laki-laki & 34 & 44 & sembuh & 10 & pria & 28 \\
\hline 21 & sembuh & 16 & * & * & 45 & sembuh & 10 & pria & 45 \\
\hline 22 & sembuh & 16 & perempuan & 40 & 46 & sembuh & 10 & perempuan & 36 \\
\hline
\end{tabular}

Sumber: Rangkuman Data Covid-19 (instagram banyuwangi_kab @banyuwangikab.go.id)

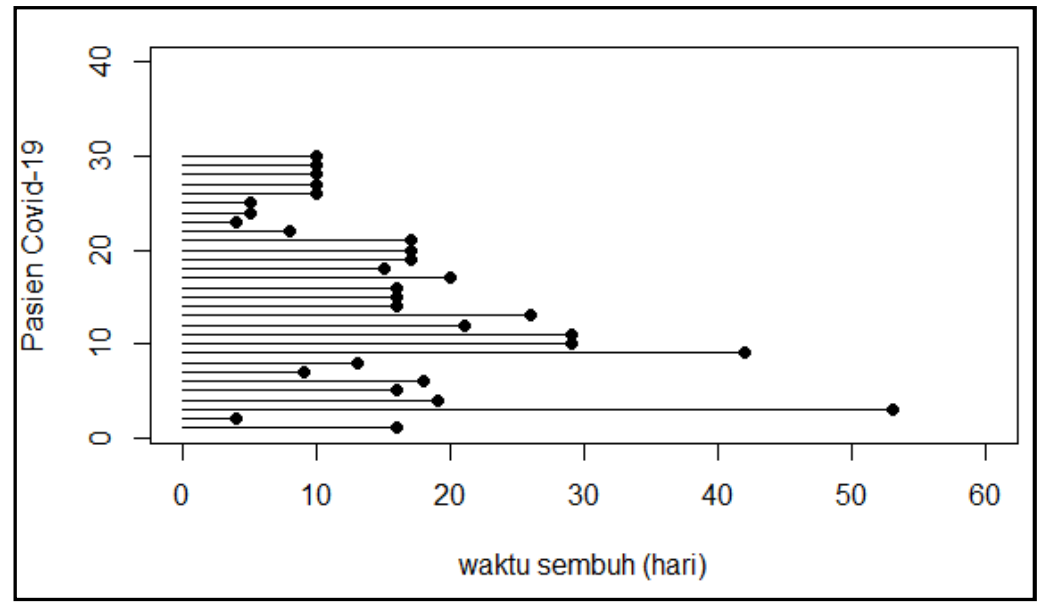

Gambar 1. Plot Data Antar Kejadian Waktu Sembuh Pasien Covid-19 di Kabupaten Banyuwangi

Gambar 1 menunjukkan bahwa waktu sembuh pasien covid-19 berbeda-beda, dengan waktu sembuh tercepat adalah 4 hari masa perawatan, dan waktu sembuh terlama adalah 53 hari masa perawatan. Adapun hasil estimasi uji Kaplan-Meier ditampilkan pada gambar 2 berikut.

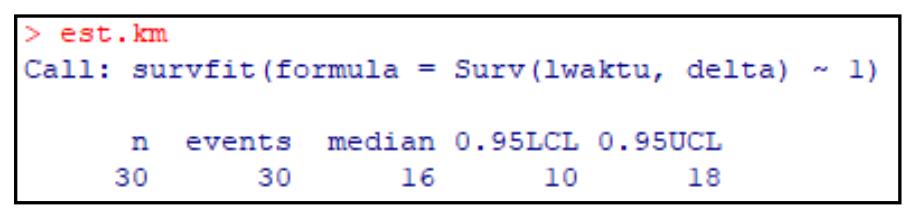

Gambar 2. Estimasi Kaplan-Meier Waktu Sembuh Pasien Covid-19 di Banyuwangi Gambar 2 menampilkan ouput hasil estimasi Kaplan-Meier. Dari output tersebut dapat dilihat bahwa secara umum lama waktu sembuh pasien covid-19 memiliki median sebesar 16 hari perawatan, dengan batas bawah median konfiden inter- 
val-nya adalah 10 hari perawatan dan batas atas median konfiden intervalnya adalah 18 hari.

Selanjutnya ditampilkan estimasi fungsi survival S(t) tersebut kedalam bentuk grafik fungsi survival S(t), seperti pada gambar 3 berikut.

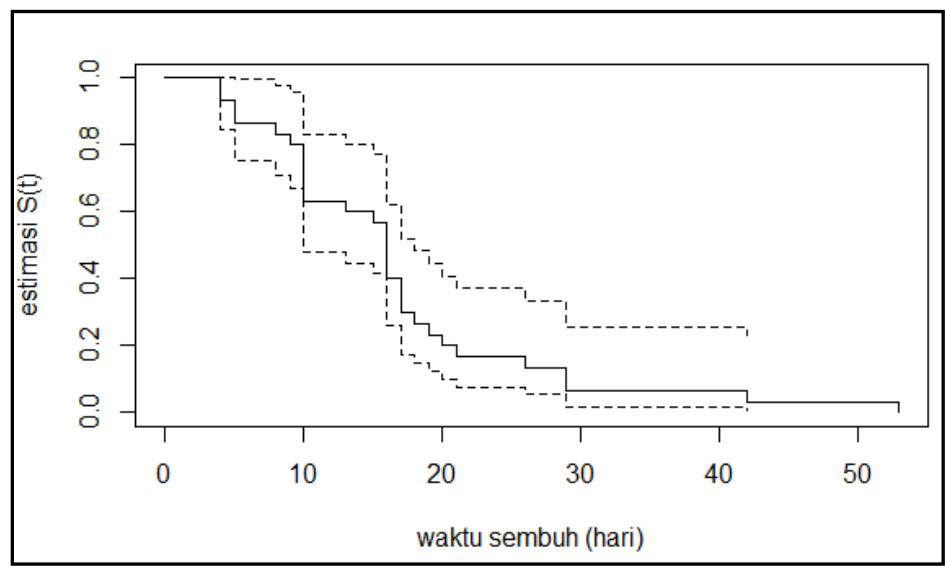

Gambar 3. Kurva Kaplan-Meier Fungsi Survival S(t) Pasien Covid-19 di Banyuwangi

Gambar 3 menunjukkan grafik fungsi survival S(t) dari lama waktu sembuh pasien Covid-19 di Kabupaten Banyuwangi, yang diketahui bahwa median waktu sembuh pasien covid-19 di Kabupeten Banyuwangi adalah 16 hari setelah di rawat oleh tenaga medis.

\section{Analisis Kaplan-Meier Faktor Jenis Kelamin Pasien}

Berdasarkan 30 sampel yang tercantum pada tabel 1, tidak semua dapat digunakan dalam analisis Kaplan-Meier untuk faktor jenis kelamin, karena terdapat 8 pasien sembuh Covid-19 yang tidak tercantumkan jenis kelaminnya pada data yang di publikasi oleh Pemkab Banyuwangi, maupun pada sumber lain yang peneliti coba temukan. Sehingga data 8 pasien tersebut menjadi data tersensor dan tidak digunakan untuk analisis. Kriteria data yang digunakan dalam analisis Kaplan-Meier faktor jenis kelamin ini adalah : (1) pasien yang diketahui informasi tanggal dinyatakan positif Covid-19 dan tanggal dinyatakan sembuh Covid-19 dan (2) pasien yang diketahui jenis kelaminnya. Sehingga untuk analisis ini sampel yang digunakan sebanyak 22 pasien dengan pasien laki-laki sebanyak 14 orang dan pasien perempuan sebanyak 8 orang.

Selanjutnya dilakukan uji Kaplan-Meier untuk pasien Covid-19 yang berjenis kelamin laki-laki, yaitu untuk mengetahui estimasi fungsi survival ( $\mathrm{S}(\mathrm{t})$ ) dan grafik fungsi survival (S(t)) lama waktu sembuh Pasien Covid-19 pada pasien laki-laki 


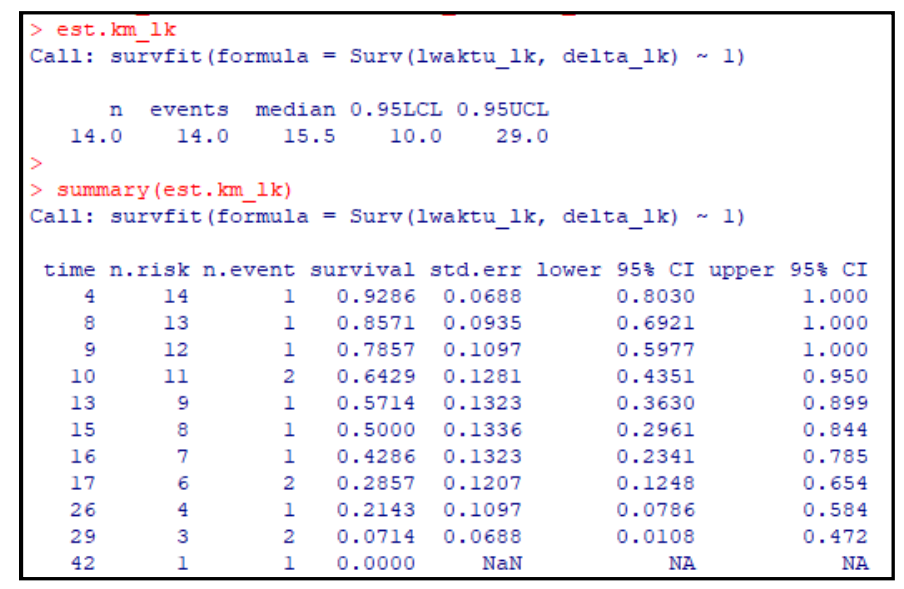

Gambar 4. Estimasi Kaplan-Meier Waktu Sembuh Pasien Covid-19 jenis kelamin laki-laki

Gambar 4. menunjukkan estimasi Kaplan-Meier untuk pasien laki-laki. Dapat dilihat bahwa fungsi survival S(t) dari waktu sembuh pasien Covid-19 laki-laki memiliki median seebsar 15,5. Sehingga dapat dikatakan bahwa median waktu sembuh pasien Covid-19 laki-laki di Kabupaten Banyuwangi adalah 15,5 hari setelah dirawat oleh tenaga medis.

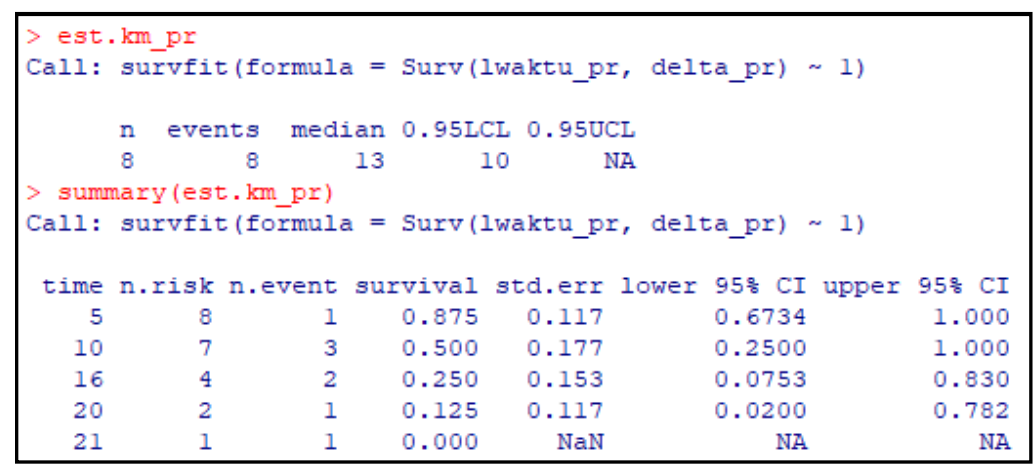

Gambar 5. Estimasi Kaplan-Meier Waktu Sembuh Pasien Covid-19 Perempuan Gambar 5. menunjukkan estimasi Kaplan-Meier untuk pasien perempuan. Dapat diketahui bahwa fungsi survival $\mathrm{S}(\mathrm{t})$ dari waktu sembuh pasien Covid-19 perempuan memiliki median sebesar adalah 13. Sehingga dapat dikatakan bahwa median waktu sembuh pasien Covid-19 perempuan di kabupaten Banyuwangi adalah 13 hari setelah dirawat oleh tenaga medis. 


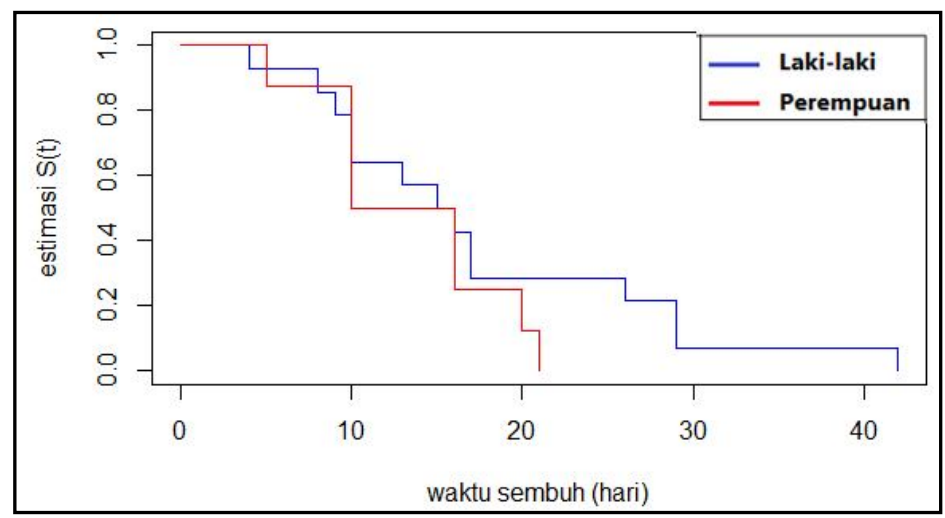

Gambar 6. Kurva Kaplan-Meier Waktu Sembuh Pasien Covid-19 Faktor Jenis Kelamin Gambar 6. menunjukkan kurva Kaplan-Meier waktu sembuh pasien Covid-19, dengan kurva merah adalah kurva waktu sembuh pasien perempuan dan kurva biru adalah kurva waktu sembuh pasien laki-laki. Berdasarkan kondisi tersebut, dapat diketahui bahwa pasien perempuan memiliki peluang tahan hidup/ peluang sembuh dari Covid-19 lebih cepat dibandingkan pasien laki-laki. Karena pada grafik menunjukkan kurva jenis kelamin perempuan berada dibawah kurva laki-laki, maka dapat disimpulkan bahwa kelompok pasien perempuan memiliki peluang sembuh lebih besar dibandingkan pasien laki-laki.

\section{Analisis Kurva Kaplan-Meier Faktor Usia Pasien}

Selanjutnya dilakukan analisis untuk mengetahui fungsi survival S(t) lama waktu sembuh pasien Covid-19 di kabupaten Banyuwangi berdasarkan faktor usia. Data pada tabel 1, dibagi menjadi 2 kelompok usia, yaitu : (1) kelompok pasien usia kurang dari 40 tahun dan (2) kelompok pasien usia 40 tahun keatas. Kemudian dihitung kurva Kaplan-Meier pada data tersebut.

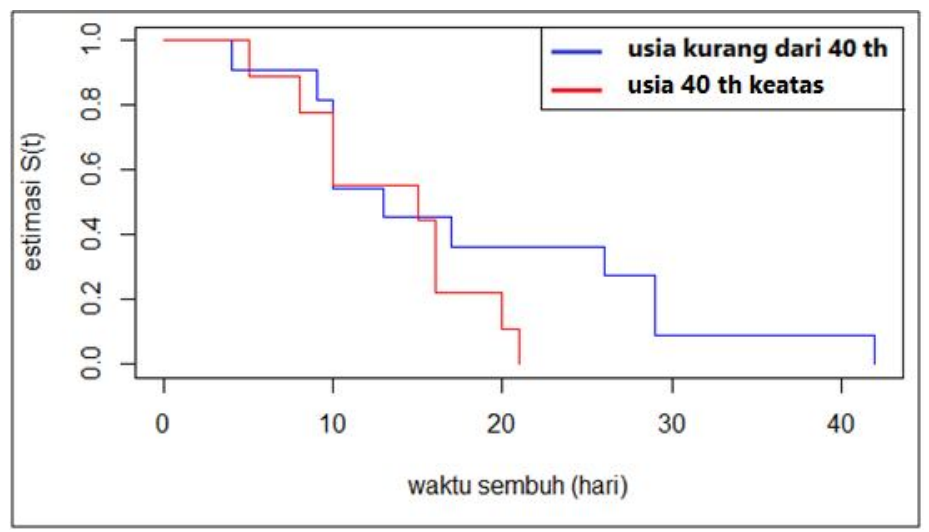

Gambar 7. Kurva Kaplan-Meier Waktu Sembuh Pasien Covid-19 Faktor Jenis Kelamin 
Gambar 7. dapat diketahui bahwa pasien yang berusia 40 th keatas memiliki peluang tahan hidup/ peluang sembuh dari Covid-19 lebih cepat dibandingkan pasien yang berusia kurang dari 40 th.

\section{Uji Log-Rank}

Uji log-rank dilakukan untuk mengetahui apakah fungsi survival lama waktu sembuh pasien covid-19 pasien laki-laki sama dengan pasien perempuan atau tidak. Pasien laki-laki diberi simbol 1 dan pasien perempuan diberi simbol 0.

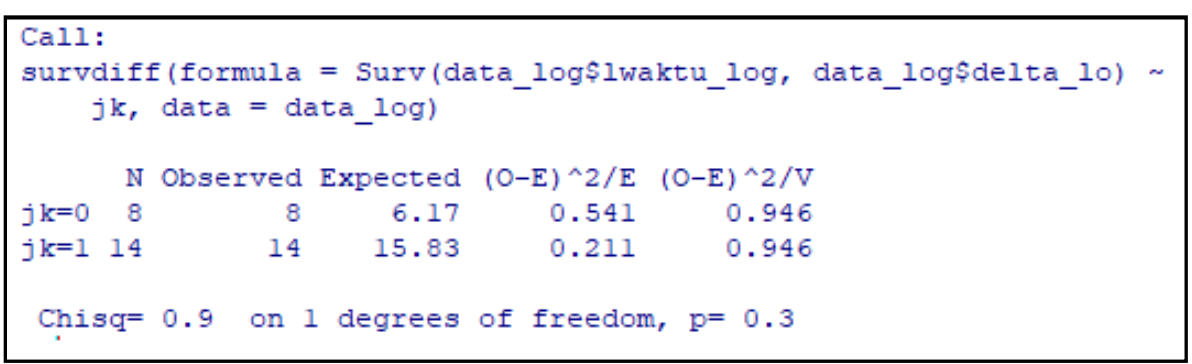

Gambar 8. Estimasi Uji Log-Rank Waktu Sembuh Pasien Covid-19 Menurut Jenis Kelamin Hipotesis yang digunakan adalah : $\mathrm{Ho}: \mathrm{S}_{1}(\mathrm{t})=\mathrm{S}_{2}(\mathrm{t})$ dan $\mathrm{H}_{1}: \mathrm{S}_{1}(\mathrm{t}) \neq \mathrm{S}_{2}(\mathrm{t})$, dengan tingkat signifikansi $\alpha=5 \%$. Akibatnya dapat disimpulkan bahwa terjadi gagal tolak Ho karena nilai $\mathrm{p}$-value $=0,3>\alpha=0,05$. Sehingga dapat dikatakan bahwa tidak terdapat perbedaan yang signifikan antara fungsi survival $\mathrm{S}(\mathrm{t})$ lama waktu sembuh pasien Covid-19 laki-laki dan perempuan.

Selanjutnya dilakukan uji log-rank antara pasien usia kurang dari 40 tahun dan pasien usia 40 ke atas. Pasien usia kurang dari 40 tahun diberi simbol 1 dan pasien usia 40 tahun ke atas diberi simbol 0 .

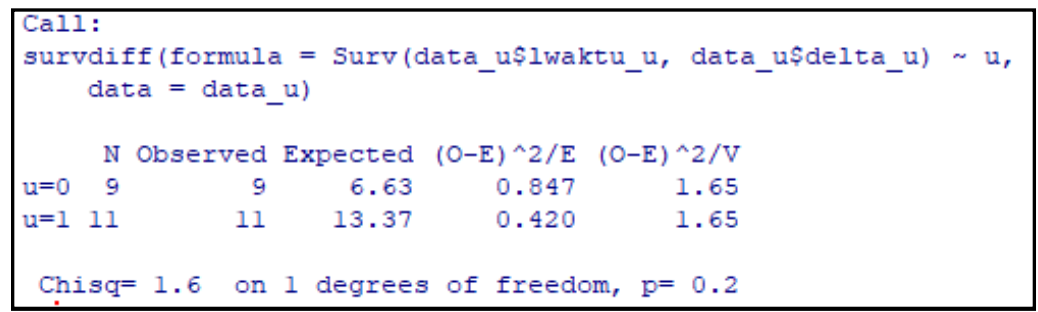

Gambar 9. Estimasi Uji Log-Rank Waktu Sembuh Pasien Covid-19 Menurut Usia Pasien Hipotesis yang digunakan adalah : $\mathrm{Ho}: \mathrm{S}_{1}(\mathrm{t})=\mathrm{S}_{2}(\mathrm{t})$ dan $\mathrm{H}_{1}: \mathrm{S}_{1}(\mathrm{t}) \neq \mathrm{S}_{2}(\mathrm{t})$, dengan menggunakan tingkat signifikansi $\alpha=5 \%$. Akibatnya dapat disimpulkan bahwa terjadi gagal tolak Ho karena nilai $p$-value $=0,2>\alpha=0,05$. Sehingga dapat dikatakan bahwa tidak terdapat perbedaan yang signifikan antara fungsi survival $\mathrm{S}(\mathrm{t})$ lama waktu sembuh pasien Covid-19 untuk usia kurang dari 40 tahun dan pasien usia 40 tahun keatas. 


\section{Kesimpulan}

Berdasarkan hasil dan analisis data yang telah diberikan, dapat diperoleh beberapa kesimpulan dalam penelitian ini. Fungsi survival S(t) lama waktu sembuh pasien Covid-19 di kabupaten Banyuwangi memiliki median 16 hari perawatan dengan fungsi survival S(t) lama waktu sembuh pasien Covid-19 untuk pasien berjenis kelamin laki-laki memiliki median 15,5 hari perawatan, sedangkan untuk pasien berjenis kelamin perempuan memiliki median 13 hari perawatan. Secara signifikan, tidak terdapat perbedaan lama waktu sembuh pasien covid-19 di kabupaten Banyuwangi untuk kelompok jenis kelamin, artinya pasien Covid-19 laki-laki dan perempuan mempunyai peluang lama waktu sembuh yang sama. Secara signifikan, tidak terdapat perbedaan lama waktu sembuh pasien covid-19 di kabupaten Banyuwangi untuk kelompok usia pasien, artinya pasien Covid-19 usia kurang dari 40 tahun dan pasien usia 40 tahun keatas mempunyai peluang lama waktu sembuh yang sama.

\section{Ucapan Terimakasih}

Ucapan terimakasih ditujukan pada LPPM IKIP PGRI Jember yang telah memberikan bantuan baik moril maupun materil sehingga penelitian dapat dilaksanakan.

\section{Daftar Pustaka}

Banyuwangikab.go.id.(2020). Peta Sebaran Covid-19 Kabupaten Banyuwangi. Official Account Instagram Pemerintah Kabupaten Banyuwangi.

Cook, A.(2008). Kaplan Meier Estimate of S(t). Singapore:National University of Singapore

Harlan, J. (2017). Analisis Survival. Jakarta:Penerbit Gunadarma

Ikhsania, A. A. (2020). Siapa Saja Ornag Yang Rentan Covid-19 dan Lebih Beresiko?. https:/ / www.sehatq.com/ artikel/ siapa-saja-orang-yang-rentan-terinfeksi-vir us-corona 15 Oktober 2020.

Lawless, J. F. (2003). The Statistical Analysis of Recurrent Event. USA: Springer Scince Business Media Inc.

KemenkesRI. (2020). Kementerian Kesehatan RI, Covid-19 Dalam Angka, Kondisi 22 Agustus 2020. Jakarta:KemenkesRI Press 
Kusumawardani, N. A. (2016). Analisis Kurva Survival Kaplan Meier Pada Pasien HIV/ AIDS Dengan Antiretroviral Therapy (ART) di RSUD Prof.Dr.Soekandar Kabupaten Mojokerto Menggunakan Uji Log Rank. Jurnal sains dan seni ITS. Vol.5,No.1. 127-132.

Pane, M. D.C. (2020). Virus Corona. https:// www.alodokter.com/ virus-corona. 15 oktober 2020.

Yulianto, D., Notobroto, H. B., Widodo. (2017). Analisis Ketahanan Hidup Pasien Penyakit Ginjal Kronis Dengan Hemodialisis di RSUD Dr. Soetomo Surabaya. Jurnal Manajemen Kesehatan Yayasan RS Dr. Soetomo. Vol.3 No.1.99-112. 